血液透析患者は非慢性腎臓病患者に比較して心臓突然死の発症頻度が 25〜 130 倍高く, 透析治療開始後 12 時間以内と中 2 日を空けた透析治療前 12 時間以内に ピークを有する. その主な原因として血中 $\mathrm{K}^{+}$濃度の急激な変化, 虚血性心疾患や 慢性うつ血性心不全を高率に合併すること, 透析治療中に急速に減少する体液量な どによつてもたらされる交感神経系の持続的賦活化があげられる. また, 植込み型 除細動器 (ICD) による予後改善効果は不十分であり, 抗不整脈薬の使用も限定され る. 一方, 心房細動 (AF) は高齢透析患者の $30 \%$ 以上に合併する. 非慢性腎臓病患 者に合併した AFでは, 血栓性合併症を予防するワルファリン治療が最も優先され るが, 透析患者では脳出血のみならず脳梗塞発症リスクを増大させる. 以上, 透析 患者に合併した不整脈を治療する際には，その特異性を理解する必要がある.

(心電図, $2012 ; 32: 321 \sim 326$ )

I .はじめに

日本循環器学会や米国心臓協会 $(\mathrm{AHA})$, 米国心 蔵病学会 (ACC) から, 不整脈治療に関連したガイ ドラインが刊行されている. しかし，いずれのガイ ドラインも血液透析患者の特殊性を考慮していない ため, 日本透析医学会 (JSDT) では独自に「血液透析 患者における心血管合併症の評価と治療に関するガ

\begin{tabular}{|ll|}
\hline Keywords & ・血液透析 \\
& ・心臓突然死 \\
& ・致死性心脂質不整脈 \\
& ○房細動 \\
& ・レトト・コントロール \\
\hline
\end{tabular}

東邦大学医療センター大橋病院腎臓内科

（† 153-8515＼cjkstart東京都目黒区大橋 2-17-6）
イドライン」を作成し ${ }^{1)}$, 第 4 章「不整脈・ 心臓弁膜 症」で透析患者特有の不整脈発症原因, 評価法, お よび治療に関してのステートメントとその解説がな されている.

\section{II. 疫学と病因}

血液透析患者における心臓突然死は JSDT 統計調 查では約 $5 \%{ }^{22}$, 米国腎臓データシステム (USRDS) では約 $26 \%{ }^{3)}$ と報告され，一般市民に比較して 25〜 130 倍と非常に高頻度に発症する。血液透析患者に おける心臓突然死は, 透析治療開始後 12 時間以内 と中 2 日を空けた透析治療前 12 時間以内に発症の ピークがある ${ }^{4)}$. 透析治療開始後 12 時間以内に心 臓突然死の発症が多い原因は, 透析治療における除 水に伴う交感神経系の賦活と低 $\mathrm{K}^{+}$血症が, 透析治

Sudden Cardiac Death and Dysrhythmia in Hemodialysis Patients Hiroki Hase 


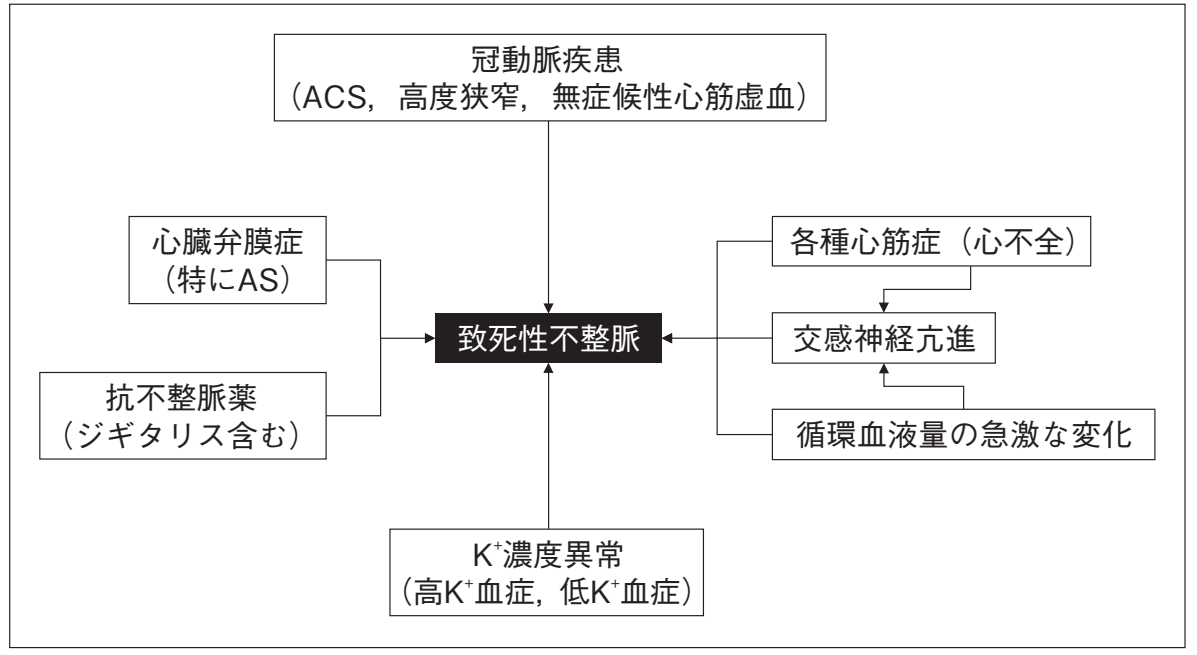

図 1

致死性不整脈発症の主な原因 ACS：急性冠症候群, AS：大動 脈弁狭窄症
療開始前 12 時間以内に多い原因は循環血液量の増 加に伴う交感神経系の賦活と高 $\mathrm{K}^{+}$血症が深く関与 しているものと考えられる. 低 $\mathrm{K}^{+}$血症は QT延長 の原因となり, torsade de pointesから心室細動 (ventricular fibrillation：VF)へと移行させる重要 な要因でもある.

致死性心室不整脈は cardiac arrest, VF, 心室粗 動, 心室頻拍(ventricular tachycardia：VT)の総称 である．血中 $\mathrm{K}^{+}$濃度異常や交感神経系の賦活以外 に, 虚血性心疾患(急性冠症候群や無症候性心筋虚 血を含む)や心不全(左室収縮・拡張不全)，弁膜症 (特に大動脈弁狭窄症), 多彩な薬剂の併用も血液透 析患者においては重大な発症原因と考えられる(図1).

高度徐脈性不整脈には洞不全症候群や洞房ブロッ ク，高度房室ブロックが含まれるが，血液透析患者 において高頻度で認められるとするエビデンスは ない.

心房細動 (atrial fibrillation：AF) と心房粗動は頻 拍性急性肺うっ血や頻拍性心筋症による慢性うっ血 性心不全の原因となるのみならず，頻拍時の血圧低 下は透析困難症の重大な要因となる。血液透析導入 患者の $12 \%$ に $\mathrm{AF}$ を認める。血液透析治療導入時 点で正常洞調律であった患者の $12 \%$ が 2 年以内に $\mathrm{AF}$ となり, $\mathrm{AF}$ を合併した血液透析患者は脳卒中 発症率や死亡率が極めて高い ${ }^{5)}$ 。また，AF は加齢
や透析期間が長くなるにしたがって合併頻度が増加 し，70歳以上の患者では 30\% 以上に認められる ${ }^{6)}$.

\section{III. 治 療}

\section{1．致死性心室不整脈に対する予防治療}

$\beta$ 遮断薬は心室期外収縮や他の不整脈発生の抑 制, 心臟突然死発症の抑制，心筋酸素需要量の低下 に有効であるとともに, 安全性が高いために薬物治 療の主軸をになっている. 左室収縮機能障害(左室 駆出率＜35\%)の血液透析患者に対するカルベジ ロール投与は全心臓血管死のみならず，心蔵突然死 も有意に減少させる ${ }^{7)}$. 心停止をきたした透析患者 の心停止以前に服薬していた薬剤と心停止後の予後 を検討した報告によると， $\beta$ 遮断薬と RA 系阻害薬 は用量依存性に予後改善効果が認められ，Ca拮抗 薬では低用量と高用量でのみ予後改善効果を認めて いる ${ }^{8)}$. I 群抗不整脈薬の使用は致死性心室不整脈 による死亡率を増加させる可能性が高いため, 慎重 投与の必要がある.VTに対するカテーテルアブ レーションは非透析患者には有用であるが, 透析患 者に有用であるとのエビデンスはない.

\section{2. 致死性心室不整脈発症時の緊急治療}

自動体外式除細動器 (automated external defibrillator：AED) はVF発症後数分以内に除細動できれ ば，患者の救命が可能な装置である。透析部門に 
AED 設置することが望ましいとの報告がある一 方，AEDを設置した透析施設と非設置施設におけ る心停止後の予後に有意差が認められないとの報告 もある ${ }^{9)}$ 。したがって, AEDの有益性に関しては 今後の検討課題である.

\section{3. 致死性心室不整脈に対する植込み型除細動器 治療}

植达み型除細動器 (implantable cardioverter defibrillater：ICD）は, 致死性心室不整脈合併透析 患者の予後改善効果を有する ${ }^{10)}$. 左室駆出率 < $35 \%$ の透析患者を対象として, ICD 治療後の生存率 の中央值は ICD 群で 8.0 年であったのに比較して, 非 ICD 群では 3.1 年と有意に低いことが報告されて いる ${ }^{11)}$ 。これらのエビデンスに基づいて，米国で は保存期慢性腎臓病 (chronic kidney disease： CKD) 患者および透析患者に対する ICD 治療が非 CKD 患者に比較して急速に伸びている ${ }^{12)}$. しかし, ICD 治療後の非 CKD 患者の死亡原因に占める心臓 突然死の割合が $10.3 \%$ であるのに比較して，透析患 者では $50 \%$ と高率の ${ }^{13)}$ ため, ICD 治療に際して患 者自身や患者家族に非 CKD 患者と同程度の治療効 果が得られない現状を十分に説明する必要がある (図2).

\section{4. 恒久的ペースメーカー植込み治療}

恒久的ペースメーカー植込みは生命予後の改善は もちろんのこと, QOLの改善も目的として透析患 者を含めて広く臨床的に用いられているが, 一方 で，過剩植达みによる医療経済上の問題も指摘され ている，恒久的ペースメーカー植込みは，進行性の 第 II 度または第 III度の房室ブロック患者で, (1) 徐 脈による明らかな臨床症状を認める場合, (2) 投与 不可欠な薬剤による徐脈の場合, (3) 3 秒間以上の心 停止または覚醒時の心室拍数が $40 /$ 分未満の場合,

(4) 房室接合部のカテーテルアブレーション後の場 合, (5) 心臓手術後の場合, (6) 進行性の神経筋疾患 に伴う場合, が絶対的適応である。 そのほか, 失神・ 痓攣・うっ血性心不全が洞結節機能低下に基づく徐 脈・洞房ブロック・洞停止によるものであることが

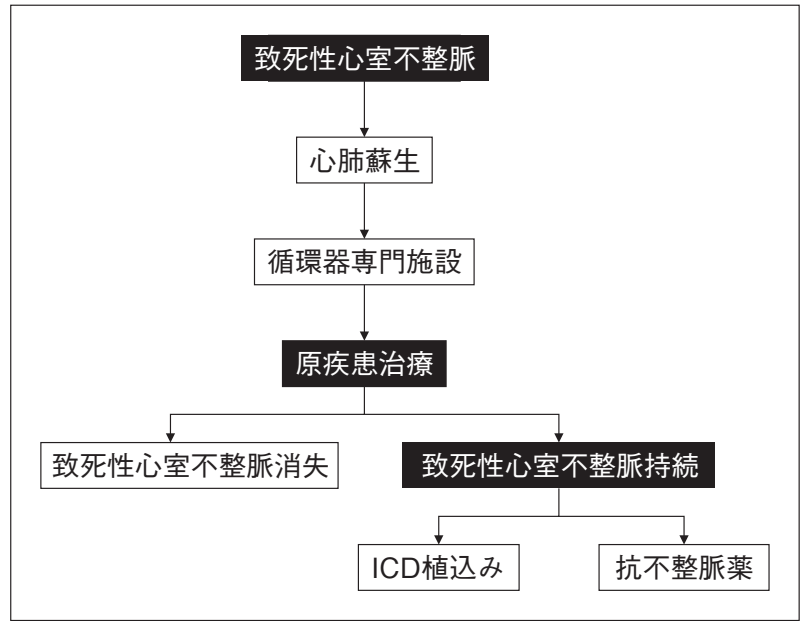

図 2 透析患者における致死性心室不整脈の治療

確認された場合や，同様の症状が徐脈性 $\mathrm{AF}$ による ものであることが確認された場合も恒久的ペース メーカー植込みの適応となる.

5. 心房細動と心房粗動に対するワルファリン治療 $\mathrm{AF}$ や心房粗動 (atrial flitter：AFL)の治療には, (1) 血栓形成予防, (2) 除細動, (3) リズム・コントロー ル，(4) 心拍数コントロールがある. 非透析患者に 合併した $\mathrm{AF} / \mathrm{AFL}$ では，血栓性合併症予防として ワルファリン投与が推奨されているが，透析患者に 対するワルファリン投与は原則禁忌である，透析患 者においては，ワルファリンやアスピリン服用患者 では非服用患者に比較して, 脳卒中の発症率が 8.3 倍増加するとの報告がある ${ }^{14)}$ 一方， ワルファリン の服用が $\mathrm{AF}$ で入院した透析患者の死亡リスクを低 下させるとする報告もある ${ }^{15)}$ 。また， $\mathrm{AF}$ 合併透析 患者の $48 \%$ では重篤な出血の既往歴があるために, 抗凝固療法が禁忌であったとの報告 ${ }^{16)}, \mathrm{AF}$ 合併透 析患者 1,671 名を平均 1.6 年間観察した検討におい て，ワルファリン服用患者では非服用患者に比較し て新規脳卒中の発症リスクが 1.93 倍高く, INR (international normalized ratio) モニターを行うこ となくワルファリンを服用している患者では, 非服 用患者に比較して脳卒中発症リスクが 2.79 倍に増 加するとの報告もある ${ }^{17)}$ 。さらに, DOPPS研究結 果によると， $\mathrm{AF}$ 患者の $16 \%$ にワルファリンが投与 


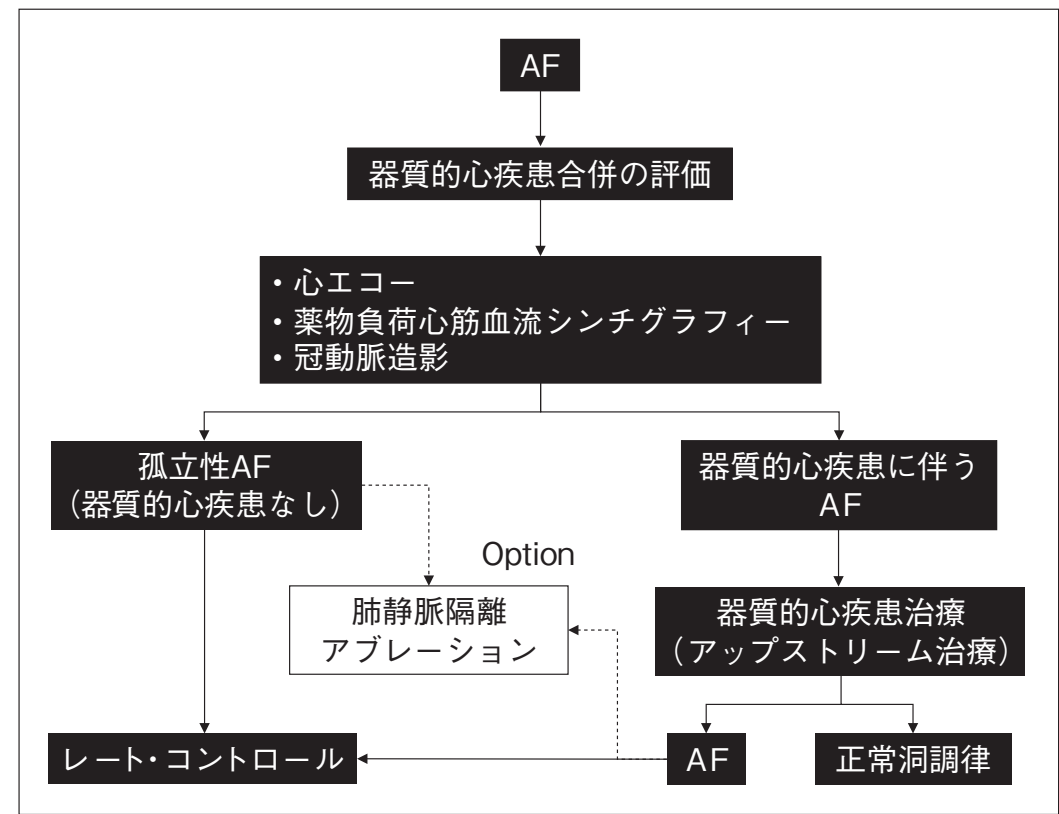

図 3

透析患者の心房細動・心房粗動に対する 治療戦略

されており，75歳以上のワルファリン服用患者で

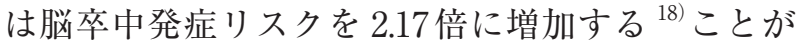
示されている。いずれも観察研究のため, ワルファ リンの有用性を評価するには，今後より大規模な介 入試験が必要と考えられる。しかし，現時点では $\mathrm{AF}$ 合併透析患者ではワルファリン使用を慎重に行 う必要がある。また，ワルファリン治療が有益と判 断された透析患者 (TIA/脳梗塞の既往, 左房内血 栓の存在, 人工弁置換術後, 僧房弁狭窄症合併)で は INRを定期的に測定し， INR $<2.0$ に維持するこ とが望ましい ${ }^{17)}$ 。さらに，透析中の患者では偽性 INR上昇を高頻度で認め, その原因として留置カ テーテルからの採血があげられる ${ }^{19)}$. したがって， PT-INRの測定に用いる血液は血管(静脈・内シャン ト・グラフトシャント)からの直接採取を推奨する.

6. 心房細動と心房粗動に対するリズム・コント ロールとレート・コントロール治療

除細動治療に関しては, 薬物療法による除細動と 電気的除細動がある。電気的除細動の絶対的適応 は，(1) 薬物療法に反応しない高頻拍性 AFで，進 行性の心筋虚血・症候性低血圧・狭心症 - 心不全を 伴う患者, (2) 高頻拍性 AFまたは血行動態が不安
定な患者, (3) 血行動態的に不安定ではないが AF による臨床症状が耐えがたい患者である，相対的適 応は，(1) AF 患者に対する長期管理戦略の一部とし て洞調律に回復することが有用な場合，(2) 症候性 あるいは再発性 AFを管理する上で，患者自身が $\mathrm{AF}$ 発生時に電気的除細動を繰り返し行うことを選 択した場合である. 非維持透析患者では, 除細動後 の血栓・塞栓症発生予防のために一定期間の経口抗 凝固療法を行うことが推奨されているが，透析患者 を対象とした報告はない。薬物療法による除細動に は抗不整脈薬を用いることになるが，いずれも QT 延長や QRS幅拡大からの催不整脈作用を有するた め, 維持透析患者では投与量や投与後の血中濃度, 心電図監視が必要である。非透析 $\mathrm{AF}$ 患者を対象と したリズム・コントロールとレート・コントロール を比較したメ夕解析では, 入院の必要率が心拍数コ ントロール群で有意に $(\mathrm{p}<0.01)$ 少なかったもの の, 死亡率, non-CNS bleeding 発症率, 虚血性脳 卒中発症率には有意差を認めておらず，またリズ ム・コントロール群では心室頻拍や徐脈, QT延長 を高率で合併するとしている ${ }^{20)}$. 多様な降圧薬を 服用し，透析治療に伴う血中 $\mathrm{K}^{+}$濃度变化が著しい 
患者に関して，非透析患者におけるエビデンスを否 定する理由はない。したがって， $\beta$ 遮断薬(カルベ ジロールなど)や非ジヒドロピリジン系 Ca拮抗薬 (ジルチアゼム, ベラパミル)によるレート・コント ロール治療を中心とする。また，透析患者に対する ジゴキシン投与は容易にジゴキシン中毒をきたすこ と ${ }^{21)}$ ， 入院を要する $\mathrm{AF}$ 関連因子であることが報告 され ${ }^{15)}$, 血中消失時間が長く, 他の薬剤との相互 作用も多いため, 安易なジゴキシン投与は避けたほ うが望ましい。レート・コントロールの目標は，従 来は安静時心拍数 $80 /$ 分未満で中等度の運動時心拍 数を $110 /$ 分未満としていたが，安静時心拍数を 110/分にコントロールすることがより予後改善に 有用との報告もある ${ }^{22)}$ 。 カテーテルアブレーショ ンは, 左房拡張を合併していない症候性・再発性 $\mathrm{AF}$ 患者には, 薬物治療に代わる治療法として合理 的である。しかし，透析患者における有用性に関す るエビデンスはないものの, CKD 患者では非 CKD 患者に比較して AFの再発リスクが約 2.1 倍高い ${ }^{23)}$ ことを考慮すると，透析患者における再発率も高頻 度である可能性を否定できない(図 3)。今後, 透析 患者を対象としたさらなる検討が必要である.

\section{〔文献〕}

1) 平方秀樹, 新田孝作, 友 雅司, 秋葉 隆, 伊苅裕二, 井関邦敏, 稲葉雅章, 井上 亨, 尾崎重之, 熊田佳孝, 小林修三, 常喜信彦, 庄司哲雄, 椿原美治, 鶴屋和彦, 田部井薰, 西村眞人, 長谷弘記, 平田純生, 藤井秀毅, 藤元昭一, 横井宏佳, 島本和明, 久木山清貴: 血液透析 患者に扔ける心血管合併症の評価と治療に関するガイ ドライン. 日本透析医学会雑誌, $2011 ; 44: 337 \sim 425$

2) Nakai S, Masakane I, Akiba T, Shigematsu T, Yamagata K, Watanabe Y, Iseki K, Itami N, Shinoda T, Morozumi K, Shoji T, Marubayashi S, Morita O, Kimata N, Shoji T, Suzuki K, Tsuchida K, Nakamoto H, Hamano T, Yamashita A, Wakai K, Wada A, Tsubakihara Y : Overview of regular dialysis treatment in Japan as of 31 December 2006. Ther Apher Dial, $2008 ; 12: 428 \sim 456$

3 ) http : //www.usrds.org/adr.aspx

4) Bleyer AJ, Hartman J, Brannon PC, Reeves-Daniel A,
Satko SG, Russell G : Characteristics of sudden death in hemodialysis patients. Kidney Int, $2006 ; 69$ : $2268 \sim 2273$

5 ) Vázquez E, Sánchez-Perales C, Lozano C, GarcíaCortés MJ, Borrego F, Guzmán M, Pérez P, Pagola C, Borrego MJ, Pérez V : Comparison of prognostic value of atrial fibrillation versus sinus rhythm in patients on long-term hemodialysis. Am J Cardiol, 2003 ; 92 : $868 \sim 871$

6 ) Genovesi S, Pogliani D, Faini A, Valsecchi MG, Riva A, Stefani F, Acquistapace I, Stella A, Bonforte G, DeVecchi A, DeCristofaro V, Buccianti G, Vincenti A : Prevalence of atrial fibrillation and associated factors in a population of long-term hemodialysis patients. Am J Kidney Dis, $2005 ; 46: 897 \sim 902$

7 ) Cice G, Ferrara L, D'Andrea A, D'Isa S, Di Benedetto A, Cittadini A, Russo PE, Golino P, Calabrò R : Carvedilol increases two-year survivalin dialysis patients with dilated cardiomyopathy : a prospective, placebocontrolled trial. J Am Coll Cardiol, 2003 ; 41 : $1438 \sim 1444$

8) Pun PH, Lehrich RW, Smith SR, Middleton JP : Predictors of survival after cardiac arrest in outpatient hemodialysis clinics. Clin J Am Soc Nephrol, 2007 ; 2 : $491 \sim 500$

9) Lehrich RW, Pun PH, Tanenbaum ND, Smith SR, Middleton JP : Automated external defibrillators and survival from cardiac arrest in the outpatient hemodialysis clinic. J Am Soc Nephrol, 2007; 18 : $312 \sim 320$

10) Herzog CA, Li S, Weinhandl ED, Strief JW, Collins AJ, Gilbertson DT : Survival of dialysis patients after cardiac arrest and the impact of implantable cardioverter defibrillators. Kidney Int, $2005 ; 68$ : $818 \sim 825$

11) Hiremath S, Punnam SR, Brar SS, Goyal SK, Gardiner JC, Shah AJ, Thakur RK : Implantable defibrillators improve survival in end-stage renal disease : results from a multi-center registry. Am J Nephrol, 2010 ; 32 : $305 \sim 310$

12) Herzog CA, Mangrum JM, Passman R : Sudden cardiac death and dialysis patients. Semin Dial, 2008 ; $21: 300 \sim 307$

13) Cheema A, Singh T, Kanwar M, Chilukuri K, Maria V, Saleem F, Johnson K, Frank J, Pires L, Hassan S : Chronic kidney disease and mortality in implantable cardioverter-defibrillator recipients. Cardiol Res Pract, $2010 ; 2010$ : 989261

14) Wiesholzer M, Harm F, Tomasec G, Barbieri G, Putz D, Balcke $\mathrm{P}$ : Incidence of stroke among chronic 
hemodialysis patients with nonrheumatic atrial fibrillation. Am J Nephrol, 2001 ; 21 : 35 39

15) Abbott KC, Trespalacios FC, Taylor AJ, Agodoa LY : Atrial fibrillation in chronic dialysis patients in the United States : risk factors for hospitalization and mortality. BMC Nephrol, $2003 ; 4: 1 \sim 10$

16) To AC, Yehia M, Collins JF : Atrial fibrillation in haemodialysis patients : do the guidelines for anticoagulation apply? Nephrology (Carlton), 2007 ; 12 : $441 \sim 447$

17) Chan KE, Lazarus JM, Thadhani R, Hakim RM : Warfarin use associates with increased risk for stroke in hemodialysis patients with atrial fibrillation. J Am Soc Nephrol, 2009 ; 20 : 2223 2233

18) Wizemann V, Tong L, Satayathum S, Disney A, Akiba T, Fissell RB, Kerr PG, Young EW, Robinson BM : Atrial fibrillation in hemodialysis patients : clinical features and associations with anticoagulant therapy. Kidney Int, $2010 ; 77$ : 1098 1106

19) Delate T, Witt DM, Jones JR, Bhardwaja B, Senser M : Falsely elevated international normalized ratio values in patients undergoing anticoagulation therapy : a descriptive evaluation. Chest, $2007 ; 131: 816 \sim 822$

20) Kumana CR, Cheung BM, Cheung GT, Ovedal T,
Pederson B, Lauder IJ : Rhythm vs. rate control of atrial fibrillation meta-analysed by number needed to treat. Br J Clin Pharmacol, 2005 ; 60 : 347 354

21) Kaneko T, Kudo M, Okumura T, Kasiwagi T, Turuoka S, Simizu M, Iino Y, Katayama Y : Successful treatment of digoxin intoxication by haemoperfusion with specific columns for beta2-microgloblin-adsorption (Lixelle) in a maintenance haemodialysis patient. Nephrol Dial Transplant. 2001; 16 : 195 196

22) Van Gelder IC, Groenveld HF, Crijns HJ, Tuininga YS, Tijssen JG, Alings AM, Hillege HL, Bergsma-Kadijk JA, Cornel JH, Kamp O, Tukkie R, Bosker HA, Van Veldhuisen DJ, Van den Berg MP ; RACE II Investigators : Lenient versus strict rate control in patients with atrial fibrillation. N Engl J Med, 2010 ; $362: 1363 \sim 1373$

23) Naruse $Y$, Tada H, Sekiguchi Y, Machino T, Ozawa M, Yamasaki H, Igarashi M, Kuroki K, Itoh Y, Murakoshi N, Yamaguchi I, Aonuma K : Concomitant chronic kidney disease increases the recurrence of atrial fibrillation after catheter ablation of atrial fibrillation : a mid-term follow-up. Heart Rhythm, $2011 ; 8$ : $335 \sim 341$ 